\title{
Explorations on Influence of Internet Finance on Traditional Commercial Bank
}

\author{
Meijin Wei \\ Fuzhou University of International Studies and Trade, Fuzhou, China
}

Keywords: Internet, finance, Commercial Bank

\begin{abstract}
With the deep integration of internet technology and finance, Internet finance is fashionable in China in recent years. Internet finance is featured with dual natures of internet and finance, with its own unique advantages, which have long-term influence on its competitions with commercial banks, mainly in business structure and profit model. Traditional commercial banks are facing unprecedented survival pressure under the offensive of internet finance. Study developing tendency of internet finance as well as its influence on traditional commercial banks could provide better coping strategy for traditional commercial banks.
\end{abstract}

\section{Introduction}

Due to unceasing development of internet and promotion of national policies, internet finance officially entered the historical arena in 2013. Internet finance has significant characteristics when compared with traditional finance, which enlarges financial service area, broadens financial marketing modes, and provide more conveniences for corporate financing, as well as compensates insufficient lying in some respects of traditional finance to some extent. Generalized internet finance includes mobile payment, P2P, internet banking and other financial models; with the flourish of internet finance, business of traditional commercial bank is more and more squeezed. Developing tendency of domestic internet finance at present is mainly characterized by mobilization, e-commercialization, self-financing, etc. The first feature is mobilization. Development of mobile communication technology and equipment are prerequisites of mobile payment, especially for popularization of smart-phones and tablet computer. With the development of $4 \mathrm{G}$ mobile technology and wireless network technology, integration of internet and mobile communication network is trending to be more and more obvious, lined telephone network and radio and TV network have been integrated. Mobile payment and bank card, online payment and other electric payment will be additionally integrated. The second feature is e-commercialization. Internet financing institutions provide credit services to small and micro businesses on the basis of transaction information and credit rating. The most typical one is Ali Finance, loaning limit of which is determined by corresponding rating standards. The third one is self-financing. Finance nature of internet has been rapidly and widely spread to different user group. It provides direct financing and investing services to users. Channels used for financing and loaning are gradually replaced by internet, CreditEase, Renrendai, PPdai are all representative platforms of self-financing.

\section{Influence of Internet Finance on Traditional Commercial Bank}

\subsection{Weakening payment function of commercial banks}

Under the mode of internet finance, financial resources are of high usability, transaction information is relatively more symmetrical, and transaction cost is relatively lower, which will all bring no small influence to commercial banks. Currently, fast payment could both be achieved by Alipay and Tenpay, which could also provide air ticket and train ticket purchasing, customer bill and insurance paying and other services at the same time, replacing functions of commercial banks in certain aspects somewhat. At the same time high-tech internet is changing mode of payment, internet finance is also influencing medium position of commercial banks greatly. As payment intermediations, banks mainly earn the price differences by making use of inconformity of debtors' return time. With the development of internet technology, de-synchrony of time and space will be 
weakened, and banks’ positions as payment intermediaries will be shaken to some extent.

\subsection{Influence on credit business of commercial banks}

Credit business is the most basic business service of commercial banks, which is also a major way for commercial banks to gain profit. Due to risk limitation and business audit restriction, small and micro businesses can often get no commercial bank loan. While internet finance has the advantage of fast speed, wide range, low cost, data mining and other information advantages, which could be directly used for credit loan and other investing business of small and medium enterprises, so as to scramble for customer resources of banks and replace commercial banks' intermediary role, it thus impacts social status and source of revenue of commercial banks, and then influences social status and revenue of commercial banks. Meanwhile, involvement of internet finance in petty loan and other field is also encroaching original scale of credit business of commercial banks, weakening source of revenue of commercial banks, it is also absorbing scattered funds via related measures simultaneously, all of which have brought certain influences to mobility of commercial banks.

\subsection{Quickening financial disintermediation}

"Financial disintermediation" refers capital supply steers clear of commercial banking system and directly delivered to objects that need resources and financing, while it's still under financial supervision. Financing is completed in external circulation. In traditional banking transactions, banks are mainly used as financial intermediaries. According to the new financial mode, internet financial companies establish financial service platforms, and provide related service for money supply and demand. New technologies make information exchanging more open and symmetry, thus promoting enhanced transparency and participation in development of credit services. All of which are important factors quickening financial disintermediation and weakening commercial banks' intermediations. In the respect of financing, demand and supply of funds makes objects using search platform as the transaction itself to complete financing and transaction process themselves. And in the respect of payment, the third-party payment platforms could also provide automatic payment, remittance and payment services. It is an unprecedented challenge to payment intermediation status of commercial banks.

With unceasing perfecting of multi-level capital market, investors of each kind of professional institute begin to get into the internet finance field step by step. Generally speaking, share of social financing and loan of commercial banks will continue to decrease. Internet finance is of great developing power, in spite of its influence on traditional business model and profit model of commercial banks to some extent, it's too early to overthrow traditional commercial banks, as traditional commercial banks still have many unique advantages. By means of reformation, transformation and sustainable development of commercial banks themselves could be promoted. While all of which is based on a basis for raising strengths and avoiding weaknesses.

\section{Suggestions on Future Development of Commercial Banks}

\subsection{Utilizing its own advantages and fulfilling its own potentials}

The emergence of new model of internet finance will lead to profound changes in banking industry, which will also change value chain and competition pattern of financial industry. As impacts brought by internet finance cannot be underestimated, commercial banks shall fully realize the importance of online finance and have the sense of crisis, thus to change the slow and dispersive situation at present, and take online finance as the most important developing direction. Seeing from a reasonably acceptable perspective, commercial banks shall be well prepared both in theory and practice, to actively face challenges of internet finance to them. Commercial banks shall fully utilize its own advantages and fulfill its own potentials to seek innovation and breakthrough, as well as cooperation with other financial institutions and companies inside and outside the industry.

\subsection{Large commercial banks shall pay attention to small and medium enterprises}

In its business development processes, domestic commercial banks often chasing big customers 
blindly. They usually invest credit resources to large-scale listed companies, representative leading enterprises and well-known real estate companies. However, small and micro enterprises in need of capitals are seldom concerned. Conversely, online financial companies are more likely to tend to small and micro enterprises and personal loan, so as to activate social funds and offset shortcomings of commercial banks at current stage to some extent. Under the background of developing tendency of domestic financial market, circumstances for commercial banks taking large enterprises as leading customer structure is about to become the past. Commercial ideologies of commercial banks shall be changed; especially, commercial banks shall make strategic adjustment to its customers. Traditional model taking big customers as major objectives does not apply to the current situation. Middle and small-sized enterprises are becoming new customer group of commercial banks. Customer structure adjustment of a batch of commercial banks will bring immeasurable changes to commercial models of commercial banks.

Furthermore, at the same time of studying and tracing internet companies, commercial banks shall also fight for initiative of SME financing. Banks shall firstly determine and find its own customer group, so as to solve customer-oriented and market-oriented problems. For commercial banks, establishing a set of customer rating standards of medium small and micro-sized enterprises that fits them well is the premise for seeking, mining and developing premium customers of medium small and micro-sized enterprises. After standards for SMEs are developed, problems to be solved with it turn to how to find these target customer group rapidly and effectively.

\subsection{Commercial banks shall handle its competition relation with the third-party payment companies well}

The quick development of the third-party payment shocks monopoly position of commercial banks in the market. Therefore, commercial banks shall face competitions rationally. The third-party payment platform is both cooperation and competition with commercial bank. The third-party payment companies take up external payment market, while all accounts and clearings are still remained in banks. Any negative even boycott behaviors by banks could not change the situation of being pillaged. Except for strengthening its capacities in the market, commercial bank shall also strength cooperative and competitive relations. We shall make full use of our advantages, strive to develop electrical network platform P2P of micro credit and sell related financial products, and continuously improve self quality, thus to achieve win-win of commercial banks and internet finances.

\section{Conclusion}

Rise of internet finance will be definitely not a small impact to commercial banks. Standing in the position of commercial banks, under the overall background of gradual maturing of internet finance, commercial banks shall base on its core position as credit system of the whole society, by making use of its unique capital and policy resources and combing developing tendency of internet finance, to bring customers more efficient and convenient financial services. Meanwhile, they shall also strength competition for the medium and small loan business, quicken innovation of financial business and optimize service quality. Only such commercial banks could face challenges of internet finances directly.

\section{References}

[1] Ying WANG. Influence of Internet Finance on Business of Chinese Commercial Banks [J]. China Business \& Trade. 2016(26)

[2] Fei YANG. Special Rectification Storm of Internet Finance on IIts Way: Business Opportunities and Potential Risks of Commercial Banks Coexist [J]. China Banking. 2016(07)

[3] Kangning LIU. Study on Influence of Internet Finance on Business of Commercial Banks [J]. Economic Research Guide. 2016(21) 
[4] Cuili LIU. Study on Impact of Internet Finance to Business of Traditional Commercial Banks and Countermeasures [J]. China Management Information. 2016(12)

[5] Zijiang Guo. Analysis on Influence of Internet Finance on Business of Commercial Banks [J]. Market Modernization. 2016(15)

[6] Shaoyu MA. Influence of Internet Finance on Traditional Business of Commercial Banks [J]. Business. 2016(17) 